\title{
Multicultural Education in Finland: Renewed Intercultural Competencies to the Rescue?
}

\author{
Fred Dervin \\ Martina Paatela-Nieminen \\ Kaisa Kuoppala \\ Anna-Leena Riitaoja \\ University of Helsinki \\ Finland
}

This paper reviews discourses on multicultural education and the concept of intercultural competencies in the European and Nordic country of Finland. We focus on their present uses and perceptions by decision-makers, researchers, and also student teachers. Some prognosis for the future is made based on a short case study from art teacher education in this context. The case study represents an approach that replaces an understanding of intercultural competencies only grounded in knowledge with an approach grounded in criticality. In this way, the article represents an attempt to evaluate how intercultural competencies can and should be reconceptualised in global scholarship today.

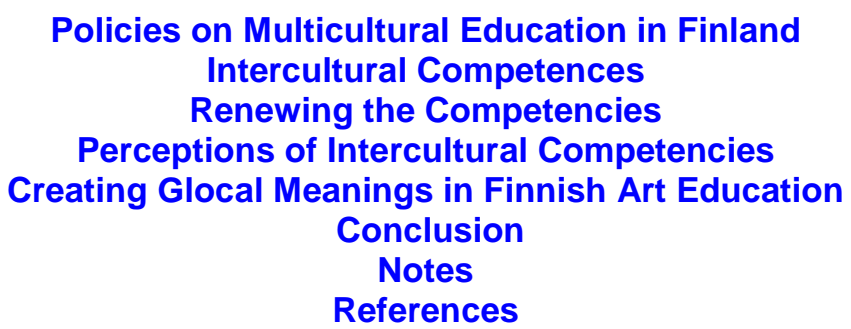

Finnish education is now known worldwide for its excellent results in most world education rankings such as Program for International Student Assessment (PISA) (Sahlberg, 2011). Having attracted worldwide attention, Finnish education has triggered "pedagogical tourism" in the country, where researchers from all over the world come to witness this "miracle." Yet very few specialists who visit Finland examine the state of multicultural education, even though Finland is increasingly a country of immigration (Talib et al., 2009). In this article we use the multifaceted notion of the multicultural but consider it as a synonym of another polysemic concept: the intercultural. The latter is often used interchangeably in global scholarship and in Finland. We agree with Holm and Zilliacus (2009) that, considering the polysemy of these notions, their dichotomization may just be "a thing of the past."

The field of multicultural education has a short history in Finnish educational sciences or teacher education compared to other countries. Furthermore there is no agreed-upon approach to multicultural education either in the Finnish academia or in schools. One concept that seems to have 
gained popularity in both research and teacher education is that of intercultural competence. This concept will be pivotal in this article as we explore the present and future of multicultural education in the Finnish context. Practically always used in the singular, we prefer to use its plural form (competencies) to develop a renewed understanding of the concept; the plural form, we believe, provides it with more legitimacy as intercultural competencies are unstable and unpredictable and tend to be a never-ending process.

In order to contribute to this special anniversary issue of IJME with its focus on the past, present, and future of multicultural education, first we review the discourse on intercultural competencies in Finland in terms of its present uses and perceptions. Then we examine the conceptualisations of intercultural competencies (what, how, and why) in relation to decisionmakers', researchers', and student teachers' discourses on the concept. In so doing the effectiveness of the concept is discussed. We also make some prognosis for its future based on a short case study from art teacher education in which we examine how critical intertextuality in creativity allows student teachers to reflect on identity and diversity. The new conceptualisations of intercultural competencies presented in this article highlight the epistemological, political, and artistic aspects of the concept.

\section{Policies on Multicultural Education in Finland}

A first look at the Finnish context suggests some kind of failure of multicultural education, especially as educational policies on the multicultural relate exclusively to immigration and international cooperation. The idea that diversity is a relatively recent phenomenon in the Finnish context is widespread (Holm \& Londen, 2010; Dervin, forthcoming); this ignores not only the ethnic, linguistic, and religious minorities of the country but also the diversities contained in social class, gender, worldviews, and areas of living both among the majority and minorities. The ideas of a homogenous Finnish society and Finnishness are mainly illusions constructed through nationbuilding, and schooling has had a central role in this construction (Gordon et al., 2000, pp. 9-22).

Räsänen (2005) has noted that in the national core curriculum for basic education (Finnish National Board of Education [FNBE], 2004) there are different aims for the (ethnic) majority and (ethnic) minorities. The aims are also constructed as if the majority and minority groups were taught separately. Multicultural education for minorities should provide them with knowledge about their "own culture" and about "Finnish culture." It should allow "immigrant" youth to develop skills and attitudes to construct and maintain a "bicultural identity" (Finnish + another national identity) in order to integrate into and to become competent/active members of Finnish society. The majority, instead, is expected to be aware of and to accept "multiculturality" in Finland, that is to say, to learn about "solid," ahistorical and a-contextualised cultural differences about people who come from abroad-not about differences within. Apart from the specific section on minority education in the 
national curriculum, the multiple diversities within majority student populations are not considered (FNBE, 2004; Holm \& Londen, 2010). Discursive reading of the policy text (i.e., FNBE, 2004) reveals that majority students are constructed as being mainly White native Finns (Riitaoja, forthcoming). This oversight is probably related to the fact that Finland is a young country (independent since 1917); as most EU countries, it is torn apart between discourses of globalization and locality. Because of this, in times of repeated economic crises, like ours, there is a large preference for locality, with Finland being an "imagined" national community.

Because of this reading, it has been argued that multiculturalism "has remained trapped within a set of nation-centric assumptions" as it "continues to address issues of cultural diversity within a national framework" (Rizvi, 2009 , p. 283). In such a context, multicultural education mainly works as a tool for "domesticating" or, as Dervin (forthcoming) puts it in reference to G. B. Shaw's 1906 play, achieving the "intercultural pygmalionism" of minority students. Although globalisation has challenged national boundaries and spaces as well as privileged epistemologies, the way multicultural education is conceptualized in Finland appears to have mainly remained untouched by these challenges.

\section{Problems with Intercultural Competencies: How to Make Them Useful?}

Be it in teacher education, higher/vocational education, professional development, or even compulsory education, the concept of intercultural competencies seems to have gained strength in Finland as a goal for its, albeit limited, understanding of multicultural education. The concept has a long history in global scholarship and has been described as extremely polysemic and problematic, especially because it includes the concept of culture (inter-cultural) which is increasingly contested (Byram, 2000; Dervin, 2010). Today, in the field of education, but also in communication, business, and health studies, it seems that intercultural competencies are sought after by many researchers and practitioners-even if they are not always sure what that entails.

In language education, one of the main advocates of the concept is British researcher Michael Byram (1997) who has contributed to conceptualising and renewing the competencies. For Byram (2000), intercultural competencies symbolise the capacity "to see relationships between different cultures-both internal and external to a society-and to mediate, that is interpret each in terms of the other, either for themselves or for other people" (p. 9). He adds that intercultural competencies also consist in being able to understand critically or analytically that one's "own and other cultures' perspective is culturally determined rather than natural" ( $p .9)$. Byram's definition has been influential in language education especially in the way it has allowed researchers and practitioners alike to move away from a mere emphasis on culture to a more critical and reflexive approach. Dervin's (2010) review of how intercultural competencies have been dealt with in 
various fields of research has demonstrated that his take on the concept is very similar to researchers' in other fields, such as intercultural communication (Deardorff, 2009; Bennett, 2004 ${ }^{1}$ ). In what follows, we review some aspects of these definitions that remain problematic. This will allow us to critically discuss an understanding of intercultural competencies that seems to be widespread in Finnish scholarship and education.

"I am going abroad and I need intercultural competence." This quote is from a student teacher in a Finnish Department of Education. When asked to explain her insistence on acquiring intercultural competence before a stay abroad, she responded that she wanted to learn how to "respect other cultures." She added, "My professors have told me that this is the main goal of interculturality."

One of the first challenging issues with intercultural competencies is the use, overuse, and abuse of the "old and tired" concept of culture (Breidenbach \& Nyíri, 2009, p. 10). In Finnish policy documents or in Byram's definition mentioned earlier ("to see relationships between different cultures"), the "cultural" concept is omnipresent. Quite often, the "-cultural" of the "intercultural" (or of the multi-cultural) takes over and deletes the "inter-": i.e., the relations between people (intersubjectivities), spaces, and times. For Holliday (2010, p. 39), the list-like and behaviourally-prescriptive approach to cultures ("do this - don't do that") is extremely ideological and too static to allow interlocutors to appreciate the diverse diversities of the Other and the Self (Dervin, 2012). To illustrate, let us quote Breidenbach and Nyíri (2009) who denounce the use of Confucianism in Europe and elsewhere to talk about Chinese students. They write, 'Using 'Confucianism' to explain the values of 1.4 billion Chinese is surely as absurd as trying to derive the behavior of contemporary Europeans from the Bible or from Plato's Republic" (p. 50). Such elements are often presented as normal by many educators or researchers (Debono, 2011). Such an approach gives the impression that intercultural competencies can be acquired for good rather than developed contextually and as part of lifelong learning.

The unproblematised essentialist concept of culture is also present in many Finnish studies that aim to evaluate or improve intercultural competencies (Talib et al., 2009). In many such studies, the focus has been on different "coloured others" while the position of the majority has remained an unrecognised and non-problematised norm.

This leads us to another misconception about intercultural competencies in Finland, a misconception which Dervin (2012) has labelled a "differentialist bias." Cultural difference, understood as racial/ethnic difference, is often exclusively the basis of models of intercultural competencies. For Phillips (2010), this limited understanding of cultural difference often leads to cultural hierarchy: "There are said to be 'better' and 'worse,' 'more advanced,' and 'more backward' cultures" (p. 20). What this approach ignores is the fact that "each of us lives in a web of cultural references and meanings" (Phillips, p. 61). This makes it difficult to define difference as national or cultural because differences emerge out of the intersection of many and varied identity markers. The future of multicultural education and intercultural competencies might rest on taking into account similarities across national 
boundaries rather than solely differences; this would lead to a more complex and less one-sided picture of intercultural encounters.

\section{Renewing the Competencies: From Knowledge-Based to Critical Competencies?}

In research, but also in practice, many critical voices are being heard in relation to a solely knowledge-based approach to intercultural competencies. In the knowledge-based approach, cultures are presented as being the "explanations for all": i.e., multicultural encounters occur through the encounters of (national) "cultures" only (Phillips, 2010). But, according to Breidenbach and Nyíri (2009), it is now important to concentrate on "the critical ability to question the implicit and explicit assumptions behind cultural claims and the power dynamics that they may be concealing" (p. 340). In other words, what these scholars suggest, and what other scholars are supporting, is that intercultural competencies should allow criticality towards the concept of culture and the related power imbalance that it can produce (Abdallah-Pretceille, 2003; Holliday, 2010; Piller, 2011; Dervin, 2012). For example, when comparing cultures, one of the cultures is often presented implicitly as being better than the other one. These scholars all share a socioconstructionist and intersubjective approach to both multicultural education and intercultural competences. This means that they take into account the fact that encounters take place in specific contexts (a school, a café, etc.) and with specific interlocutors (parents, teachers, principals, etc.) and that these intervene in the creation of identities and "cultures."

Popkewitz and Lindblad (2000) have conceptualised research on diversities and education through "equity problematic" and "knowledge problematic" studies. These conceptualizations allow us to define what we mean by "critical." Equity problematic study is already widespread in the Finnish context and "incorporates the principle of equal opportunity to learning regardless of children's race, gender, or ethnic background" (Lappalainen, 2009 , p. 75). This is in line with James Banks' idea of Equity Pedagogy in the American field of multicultural education (2008).

The socio-constructivist and intersubjective approach described above is very similar or complementary to the other approach described by Popkewitz and Lindblad (2000), entitled knowledge problematic studies. The focus of these is on systems of reason or representations of certain identities (e.g., "White," "female") that are constructed and put on the scene in educational contexts (Lappalainen, 2009). Although there is in Finland a criticism of an essentialist conception of culture, especially among equityoriented multicultural educationalists, the problematising of epistemologies (i.e., knowledge and knowing) has not been common in Finnish multicultural education (Andreotti, 2011). Equity and inclusion-oriented multicultural education is lacking on the question of knowledge and representation in the reproduction of differences and exclusion. 


\section{Perceptions of Intercultural Competencies in a Teacher Education Programme in Finland}

Having concentrated on policy and research discourses in the previous sections, we are now examining the voices of students. This section explores student teachers' views on intercultural competencies in an international teacher education programme at the University of Helsinki in the capital city of Finland $^{2}$. The programme, entitled Subject Teacher Education Programme (STEP), is an English-medium programme geared for both "native-born Finnish" and "foreign-born Finnish" students aiming to become teachers in Finnish secondary education. The programme was implemented to allow nonFinnish speaking students to find a job in Finnish schools. A few years ago, a short one-credit introductory course on multiculturality was included in subject teacher education, but a new larger module on diversities, including courses on intercultural competencies and special education, has replaced it in the STEP curriculum in autumn 2012.

In 2011, STEP admitted 20 students with either an Arts or Science major, of whom eight were native-born Finnish and 12 were foreign-born individuals originating from other countries such as Bulgaria, Britain, and India. Because of their multicultural backgrounds, we were interested in knowing how STEP student teachers defined intercultural competencies or what multiculturality meant for them. Importantly, the students were interviewed before they had taken a course on multicultural education. Since we concentrate on Finnish education, in this article, we discuss what we learned about the viewpoints of these Finnish student teachers in the group.

Every student acknowledged the benefit of learning about the varied viewpoints of people who came from different backgrounds and different disciplines and who had, for example, done their basic schooling in different educational systems. One of the main reasons why the Finnish students had wanted to apply to the programme was specifically that they would get to interact with people from different countries. Many of the students said, however, that they had not really considered the concept of multiculturality before, or what it actually meant for them, how it should manifest itself, or how it should be taken into account in the programme. In the following quotes, two students react to the word "intercultural." Their responses are representative of others' understandings:

Student 1: ["Intercultural" means] If you go to some other country or surroundings you can cooperate with other people in a sort of natural way. There are no extra barriers compared to your own country.

Student 2: I'm not even sure what [interculturality] means.... It brings to my mind some kind of interaction between cultures.... If you have a multicultural group, for example, then you have...people from different cultures in that group, but if you have something that is intercultural then you just have some kind of interaction between two cultures.

While the first student mentions cooperation with "other people" (meaning people from the foreign country or "surroundings") to define the 
"intercultural," the other student talks in terms of "interaction between cultures." These are two very general definitions that we have critically reviewed in the previous sections.

The students were also asked what should be done or changed in STEP to make studying in the programme an actual intercultural experience. Although the students explained that multicultural issues had been brought up in discussions, not all thought that they had had enough encouragement or time to share different experiences.

Student 2: The first thing that comes to my mind is to...somehow make benefit of the experiences of the people with different backgrounds.... Make people share their experiences from different countries. And I think in many occasions that was done. We talked about different cultures and teaching in different cultures.

Student 1: [Interculturality] has been there all the time but sort of in a random way. I know the people are from other countries and then in some contexts we have discussed how it has been in this and that situation. But maybe this aspect could have been enforced more...because it's such a vast richness of this programme that you have people from different countries.... So we should compare our experiences from different countries and how things are done.

As these quotes illustrate, the students felt that having a diverse student body is a definite benefit in providing a richness to the programme because it gives a chance for the students to widen their own views by sharing and trading ideas and opinions with their peers. Yet, for many, it was difficult to actually explain the idea of intercultural competencies in their own words.

In the quote below, it was interesting how some students, like Student 4, elaborated on the forming of a STEP culture:

Student 4: Everyone was very active.... [Having people from different backgrounds] had influence on us all because we had to build this culture here for STEP. So it had influence from these different backgrounds.

In a sense what this student says is that the STEP group was able to go beyond their own "culture" to negotiate a third space between them, namely the "STEP culture".

On the whole, what these sample quotes illustrate is that the concepts of multiculturality and intercultural competencies seem to be elusive for the students. In the quotes, the word "culture" (i.e., "interaction between cultures," "people from different cultures") alternates with "countries" ("experiences from different countries," "people from different countries"). The idea of differences (vs. similarities) is also omnipresent in the quotes to qualify multiculturality. There is an absence of any discussion on justice, equity, and epistemologies. Although the students verbalise multiculturality as mainly related to people from different countries, we found it interesting that some students started using the word "culture" to describe what was being created in the international group; this could indicate a move towards a similarity-oriented approach. Listening to the students' understandings, in this way, helped us identify the need for them to be introduced to critical, socio-constructivist, and 
knowledge problematic approaches to the multicultural. We wanted to explore a method for students to reflect on and develop renewed intercultural competencies.

\section{Creating Glocal Meanings in Finnish Art Education}

How can an understanding of renewed intercultural competences be implemented in teacher education through the concept of intertextualities in art education? Intertextuality can be approached from different angles and perspectives (see Allen, 2000; Orr, 2003; Worton \& Still, 1990) but, as a helpful grounding, the term text in intertextuality refers to visual, verbal, and auditory texts studied in relation to each other. In intertextuality a text transforms other texts, connecting people, times, and places, and thus can offer strategies to study practices, meanings, subjectivity, and the construction of "heritage." In this way, intertextuality is important for a renewed understanding of intercultural competencies.

An intertextual method for art education in Finland was developed by one of the authors (Paatela-Nieminen, 2000) for understanding and creating pluralities, interculturally, intermedially, and intersubjectively. This means exploring differences and similarities and their textual relations as a space for plural meanings. In other words, instead of learning one fixed truth or insight, there are several different interpretations of representations to be studied simultaneously.

For example, when using the intertextual art method, one learns about one's own heritage and memory on the one hand and about other global memories that move beyond locality on the other hand. Through the intertextual art method, one produces local, global, and glocal (meaning global and local at the same time) competencies (see Paatela-Nieminen 2008, 2009a). This is done by studying a text in its context open-endedly (Genette, 1997b), with plural interpretations about cultural differences (Kristeva, 1984). In this way, one can understand interpretations of representations and transformations of meanings in plural ways. In addition, one can create new glocal $^{3}$ interpretations when making one's own works of art, thanks to the intertextual learning process.

Here we present one case study of a class teacher student (a student studying to be a teacher in elementary school) in the Department of Teacher Education at the University of Helsinki to illustrate this new approach to intercultural competencies. The student, Hanna, was an art education minor in 2011-12. She took part in an environmental art education course where Finnish culture and identity were studied intertextually and interculturally. The task for the students was to study "my place."

Hanna's intertextual process started with the idea of finding a proper text. This was important because students' motivation should be intrinsic to the learner in the intertextual process. Hanna started to look for something that constructs her Finnish identity in her home. On her walls she had placed several covers of vinyl records on top of each other. Her curiosity arose from the covers. She asked herself an open-ended question: what do these covers 
represent as a whole? She thought of a rug and realized that rugs were important for her in her childhood. She connected the vinyl cover "rug" to her grandmother's rug; as a child Hanna often slept near her grandmother's Karelian rug ${ }^{4}$.

Later on, Hanna studied several rugs similar to her grandmother's (Genette, 1997a). Her visual image was made from vinyl covers, rock band flags from the 80-90's, Marimekko's textiles ${ }^{5}$ and Karelian rugs. She did research on her rug and her grandmother's and found a difference between them that interested her in relation to identity. Having been exiled from Karelia by the Russians after the Second World War and moved to another Finnish region, both her grandmothers were Karelian. Their local, Karelian identity was very strong. The rugs were not mere designs or decorations on the wall; they represented the grandmothers' Karelian identity. But, for Hanna, her "rug" made of vinyl covers was different as it represented both a local and global identity (glocal).

Hanna also studied the meaning of identity and its global aspects in Finnish design and cultures. She wrote about global companies and their international values. Hanna also wrote about the fact that she also appreciated what she considered to be her Finnish cultural heritage and locality. For example, she had brought from her grandmother's attic old crosscountry skis and made a headboard of them. Hanna explained that she likes to talk about her Finnish roots to her foreign friends who "couch-surf" at her place. She also claimed to appreciate plural identities and to mix global and local issues to create glocal combinations (as in the example of her rugMarimekko and international rock bands).

Hanna's work in the course was a glocal work of art that she created as part of an intercultural process. She designed a "rug" from six pieces of red clay plates. She created delicate embossed dragonflies on a few pieces and stylised reeds on other plates. These relief details were painted with ceramic colours and glazed. All the plates were connected to each other and placed on the wall as a glocal rug. In this way, she combined ideas to create the form of the rug from her original local connection to her grandmother's Karelian rug to her global vinyl record covers. The red colour, a strong local element in Karelian rugs, was seen in her choice of material (red clay). Additionally, she developed the idea of a glocal rug further by thinking of producing plates at the school where she was training. Every pupil could produce their own plate from clay. These would be linked together to form a large intersubjective work to show the intercultural identities of school children. Hanna's process was interesting because it was subjective, it allowed for multiple, non-hierarchical entry and exit points (see "rhizome" in Deleuze \& Guattari, 1987), and it was intercultural in nature.

The intertextual art method is an open-ended method to stimulate intercultural competences by offering strategies to study the construction of practices, meanings, inter-subjectivity, and heritage. The process is at best subjectively profound and allows for crossing borders interculturally. As such, in her work, Hanna was able to work from many and varied identity perspectives as she reflected on the interaction between different identity markers: region, gender, generation, and social class. Finally, intertextuality 
offers a method for understanding and creating different meanings of representations interculturally. Hanna was able to reflect on the different and enriching entry and exit points in relation to the "multicultural" in art education. The method represents a potentially rewarding and enhancing way of working with the concept of intercultural competences and can have fruitful influence on multicultural education in the increasingly heterogeneous context of Finland.

\section{Conclusion: \\ Towards a Glocally Oriented Approach to Multicultural Education and Intercultural Competencies in Finland - and Elsewhere?}

The discussion in this article has considered multicultural education and intercultural competencies through policies, theory, and educational practice in Finland. One example of renewed intercultural competencies in art education was provided as an illustration of what we consider to be a direction for positive changes.

We believe that the way forward in Finland could lie in increasingly glocally-oriented multicultural education that has its roots in cultural-historical analysis and global ethics in terms of ethical engagement with the Other (Andreotti, 2007). The short case study of Hanna's work in art education shows how she was able to acquire these understandings by reflecting critically on intertextuality in art and especially in relation to her own creativity. Such education moves both beyond the liberal order of education and the equity problematic approach towards an approach that puts stress on intersubjective experiencing, understanding, and knowing.

The aims of this kind of multicultural education are not to domesticate students into nation states or to develop competences that serve such purposes by turning them into a "typical Finn." Glocally-oriented multicultural education, and accompanying intercultural competencies, aims for understanding plural meanings.

Our next step is to take seriously into account the aspect of justice, which is now central in multicultural (teacher) education. A shift from the socio-political to the discursive and the epistemic seems to be vital in multicultural education. Andreotti (2010, p. 242) has already formulated some ideas that take these elements seriously, and these could be implemented increasingly in teacher education. We claim that Andreotti's postcolonial or post-critical global citizenship education, which lays the emphasis on not only questions of inequality and privilege but also ethical solidarity, is very useful, as it adds up to and opens new vistas for the future of multicultural education and intercultural competencies, not only in Finland, but also elsewhere. 


\section{Notes}

1. See an exhaustive lists of definitions and "tools" on the Intercultural Communication Institute in Portland (website: http://www.intercultural.org/ tools.php).

2. The data in this section are derived from an ongoing PhD study entitled "Towards International and Intercultural Teacher Education (Kuoppala)." The excerpts are from the interview data in English.

3. "Glocal" means mixing the global and the local. The student has borrowed ideas from global culture and transformed them locally. Glocal adaption corresponds to the idea of the intercultural (cf. Dervin, 2012; PaatelaNieminen, 2009b).

4. Karelia is situated in Northern Europe and is currently divided between Finland and Russia.

5. Marimekko is a Finnish fashion and design company known for its brightlycolored printed fabrics and simple patterns.

\section{References}

Abdallah-Pretceille, M. (2003). Pour un humanisme du divers. Paris, France: Economica.

Allen, G. (2000). Intertextuality. London, UK: Routledge

Andreotti, V. (2007). An ethical engagement with the other: Spivak's ideas on education. Critical literacy: Theories and practices 1(1), 69-78.

Andreotti, V. (2010). Glimpses of a postcolonial and postcritical global citizenship education. In. G. Elliot, C. Fourali \& S. Issler (Eds.), Education and social change: Connecting local and global perspectives (pp. 238-250). London, UK: Continuum.

Andreotti, V. d. O. (2011). (Towards) decoloniality and diversality in global citizenship education. Globalisation, societies \& education, 9(3), 381397.

Banks, J. A. (2008). An introduction to multicultural education. Boston, MA: Pearson/Allyn and Bacon.

Bennett, M. J. (2004). Becoming interculturally competent. In J. S. Wurzel (Ed.). Toward multiculturalism: A reader in multicultural education ( $p$ p. 62-77). Newton, MA: Intercultural Resource Corporation.

Breidenbach, J., \& Nyíri, P. (2009). Seeing culture everywhere. Seattle, WA: University of Washington Press.

Byram, M. (1997). Assessing intercultural communicative competence. Clevedon, UK: Multilingual Matters. 
Byram, M. (2000). Assessing intercultural competence in language teaching. Sprogforum, 18(6), 8-13.

Deardorff, D. (2009). The SAGE handbook of intercultural competence. London, UK: Sage.

Debono, M. (2011). Pour une pédagogie du conflit en Chine? Synergies Chine, 6, 127-140.

Deleuze, G. \& Guattari, F. (1987). A thousand plateaus: Capitalism and schizophrenia ( $2^{\text {nd }}$ ed.). Minneapolis, MN: University of Minnesota.

Dervin, F. (2010). Assessing intercultural competence in language learning and teaching: A critical review of current efforts in higher education. In F. Dervin \& E. Suomela-Salmi, (Eds.). New approaches to assessment in higher education (pp. 157-174). Bern, Switzerland: Peter Lang.

Dervin, F. (2012). Impostures interculturelles. Paris, France: L'Harmattan.

Dervin, F. (forthcoming). Rethinking the acculturation and assimilation of 'Others' in a 'monocultural' country: Forms of Intercultural Pygmalionism in two Finnish novels. Journal of Intercultural Studies.

FNBE (Finnish National Board of Education), (2004). National core curriculum for basic education intended for pupils in compulsory education [K1 to K9]. Helsinki, Finland: National Board of Education.

Genette, G. (1997a). Palimpsests. Literature in the second degree. Lincoln, NE: University of Nebraska Press.

Genette, G. (1997b). Paratexts thresholds of interpretation (J. E. Lewin, Trans.). Cambridge, UK: Cambridge University Press.

Gordon, T., Holland, J., \& Lahelma, E. (2000). Making spaces: Citizenship and difference in schools. London, UK: Macmillan.

Holliday, A. (2010). Intercultural communication and ideology. London, UK: Sage.

Holm, G., \& Zilliacus, H. (2009). Multicultural education and intercultural education: Is there a difference? In M.-T. Talib, J. Loima, H. Paavola \& S. Patrikainen (Eds.), Dialogs on diversity and global education (pp. 1128). Frankfurt, Germany: Peter Lang.

Holm, G., \& Londen, M. (2010). The discourse on multicultural education in Finland: Education for whom? Intercultural Education, 21(2), 107-120.

Kristeva, J. (1984). Revolution in poetic language (M. Waller, Trans.). New York, NY: Columbia University Press.

Lappalainen, S. (2009). Making differences and reflecting on diversities: Embodied nationality among preschool children. International Journal of Inclusive Education, 13(1), 63-78.

Orr, M. (2003). Intertextuality, debates and contents. Cambridge, UK: Polity.

Paatela-Nieminen, M., (2000). On the threshold of intercultural Alices. Intertextual research on the illustrations of the English Alice in Wonderland and the German Alice im Wunderland in intermedia research in the field of art education. Doctoral thesis in the form of a 
multimedia on CD. University publication series A 29 (sold out). Helsinki: The University of Art and Design.

Paatela-Nieminen, M. (2008). Intertextual method for art education applied in Japanese paper theatre - A study on discovering intercultural differences. In International Journal of Art \& Design Education, 27(1), 91-104.

Paatela-Nieminen, M. (2009a). Arts as a medium for intercultural communication. In H. Ruismäki \& I. Ruokonen (Eds.) Arts-contact points between cultures. Research report. Department of Applied Sciences of Education. Helsinki, Finland: University of Helsinki Press.

Paatela-Nieminen, M. (2009b). Intercultural art education towards understanding local, glocal and global cultural differences. In KOSEA, Korean Society for Education through Art, 10(2), 137-156.

Phillips, A. (2010). Gender and culture. Cambridge, UK: Polity.

Piller, I. (2011). Intercultural communication: A critical approach. Edinburgh, UK: EUP.

Popkewitz, T., \& Lindblad, S. (2000). Educational governance and social inclusion and exclusion: Some conceptual difficulties and problematics in policy and research. Discourse: Studies in the Cultural Politics of Education, 21(1), 5-44.

Räsänen, R. (2005). Etninen moninaisuus koulujen haasteena [Ethnic diversity as a challenge for schools] In Kiilakoski T., Tomperi T. and Vuorikoski M. (Eds.) Kenen kasvatus? kriittinen pedagogiikka ja toisinkasvatuksen mahdollisuus. Tampere, Finland: Vastapaino.

Riitaoja, A. L. (manuscript). Multiculturalism and social justice in schooling. Unpublished PhD manuscript.

Rizvi, F. (2008). Epistemic virtues and cosmopolitan learning. In Australian Educational Researcher 35(1), 17-35. Retrieved from http://www.aare.edu.au/aer/ online/0801c.pdf

Rizvi, F. (2009). Global mobility and the challenges of educational research and policy. In Yearbook of the National Society for the Study of Education, 108(2), 268-289.

Sahlberg, P. (2011). Finnish lessons: What can the world learn from educational change in Finland? New York, NY: Teachers College Press.

Talib, M.-T., Loima, J., Paavola, M. \& Patrikainen, S. (Eds.) (2009). Dialogs on diversity and global education. Bern, Switzerland: Peter Lang.

Worton, M., \& Still, J. (Eds.) (1990). Intertextuality: Theories and practices. Manchester, UK: Manchester University Press. 